\title{
Digital Communication Disrupting Hegemonic Power in Global Geopolitics
}

New Media Shape New World Order

Greg Simons

\begin{abstract}
The role of digital communication has been given a lot of credit and influence in its presumed power to bring about change in society, on a local or national or global level. When this presumed power for change or disruption is applied to the existing world order, there is a more nuanced outcome. In the current global order, the United States remains the unipolar hegemonic power. However, it is becoming visibly weakened, much of the harm coming from the results of its own foreign policy actions that are more guided by values and norms, rather than interest. Digital communication plays a role in both defending the current world order and challenging it. It is done in a way that renders the traditional restraints and constraints of geopolitics impotent by making space and time irrelevant, and by opening up the potential for creating global networks and relationships.
\end{abstract}

Keywords: international relations, social media, geopolitics, new media, communication, information flows

\footnotetext{
Greg Simons, PhD

Institute for Russian and Eurasian Studies at Uppsala University, Uppsala, Sweden.

Associate Professor, researcher.
}

ORCID: 0000-0002-6111-5325

ResearcherID: A-6514-2019

Scopus Author ID: 14322163700

Academia.edu: https://uppsala.academia.edu/GregSimons

E-mail: greg.simons@ires.uu.se

Address: IRES, Box 514, SE-751 20 Uppsala, Sweden

DOI: 10.31278/1810-6374-2019-17-2-108-130 


\section{INTRODUCTION}

In relative terms, the United States remains the world's sole superpower, with its political, economic and military alliances it retains the ability to act in multiple parts of the globe simultaneously. However, its power and capability has been in a noticeable decline for approximately one decade (Brooks and Wohlforth, 2016; Kofman, 2018). This is the result of the initial success of the U.S. global project in the wake of World War II and accelerated further at the conclusion of the Cold War in 1991. The U.S. grand strategy became more ideological in nature, seeking to "convert" other countries in its image. Ultimately the U.S. overestimated its capacity, political and cultural abilities that have resulted in repeated disasters that undermine its own interests and security, such as the results of the armed conflicts in Iraq and Libya (Lukin, 2016). This is seen in the geopolitics of communicating representation of actors and events.

The increasing use of the concept and notion of a new Cold War is clearly noticeable in the academic and mass media domains. Interestingly, such geopolitical representations are a combination of communicating "old-style" geopolitics of polemic confrontation by powers in space. However, it is also a means of popular geopolitics through presenting and communicating complex events in a highly simplified manner to mass audiences (Ciuta and Klinke, 2010; Browning, 2018), which is a means of producing binary opposing realities in the evolving global order.

This paper seeks to track and examine the claims of an evolving world order, where the existing U.S.-led, Western-centric world order is being disrupted and challenged via digital means. The first step is to understand the underlying geopolitical reasons for this evolution. This is to be followed by an analysis of the implications for geopolitics as a concept and a practice with the influence of new media on the geopolitical landscape. The role of the information and communication sphere is the topic of the next section, where the effects of information and communication in challenging or bolstering the international order are visited. In the final section on the concept of hegemony in a global order, we will discuss how it is 


\section{Greg Simons}

being challenged and defended, and in what direction this evolution of the world order is heading.

\section{CONCEPT AND PRACTICE OF GEOPOLITICS}

When understanding the politics of geopolitics, it is necessary to point to both perception and outcomes. "Geopolitics is not just a way of seeing. It is also the actions and outcomes that simultaneously transform spaces, places and politics" (Flint, 2017, p. 302). Thus, geopolitics can be seen as both a practice and a representation (Flint, 2017 , p. 36). In a traditional academic and tangible sense it involves the study of the geography of international politics, with a focus on the relationship between the physical environment (territory, locations, resources and so forth) and the conduct of foreign policy. Ó Tuathail and Agnew stress that "the study of geopolitics is the study of the spatialization of international politics by core powers and hegemonic states" (Ó Tuathail and Agnew, 1992, p. 192). Their focus is on the representation of the world, which is characterized by certain types of places, peoples and dramas. More specifically, geopolitics should "be viewed as the effects of space, topography, position and climate on political behaviour" (Starr and Siverson, 1990, p. 235).

Not long after the end of the Cold War, Brzezinski (1997b) noted that the United States needed to gain and retain control of Eurasia in order to assure global dominance. Part of the task was therefore to prevent any one particular actor or constellation of actors from getting the capability of challenging U.S. global hegemony. At the beginning of the new century, Cohen (2003, p. 33) noted that there is an increase in the number of the world's major and regional powers, and also a strengthening of global and regional organizations. However, he saw this as not being sufficient to eliminate disturbances in the international system, with global terrorism and irredentist wars causing considerable turmoil.

The United States views itself as an "indispensable" power, which is based upon the notion of its unchallenged superiority in military, economic, technological, and cultural power. There was also the belief that there could be no single actor with sufficient power and re- 
sources to challenge the U.S. global hegemony (Brzezinski, 1997a). However, this necessitates preventative measures to ensure that other powers or blocks of powers cannot gain power and influence. A quote from Zbigniew Brzezinski (1997b) illustrates the underlying reason and motivations for influencing regionalisms. "In brief, for the United States, Eurasian geostrategy involves...three grand imperatives...to prevent collusion and maintain security dependence among the vassals, to keep the tributaries pliant and protected, and to keep the barbarians from coming together." Although understanding the tangible and practical aspects of this strategy is important, understanding and anticipating the intangible communicational aspects is likely to bring greater benefits. This is owing to the contagious psychological basis of such policy and actions. In light of Brzezinski's observations pertaining to the goals of U.S. geostrategy, which can be seen within the context of geopolitics, its very definition is essential to understanding how processes and events are managed by international actors: "Geopolitics is, definitionally, the art and process of managing global rivalry; and success, again definitionally, consists at a minimum of consolidating the strength and cohesion of the group of nations which form the core of one's power position, while preventing the other side from extending the area of its domination and clientele" (Jay, 1979, p. 486).

It is a process that is simultaneously defined and constrained by the factors of time and space. This is something that has been played out in international relations throughout human history. The only constant is the basic fact that empires and hegemonies rise and then ultimately fall. This has been seen in recent global history too. Foster (2006) refers to the "new geopolitics of empire" that was referenced to the fall of the Berlin Wall in 1989 and the rapid collapse of the Soviet Union and that saw the rise of a unipolar global order which was no longer checked and balanced in the former bipolar global order. The end of the Cold War and the collapse of the Soviet Union in 1991 put an end to a militarized, but highly structured conflict between the two superpowers. With the end of the Cold War, regionalisms achieved much greater significance and importance, especially within the context of economic globalization (Rumley, 2005; Tsantoulis, 2009; 


\section{Greg Simons}

Vilanova, 2013). What came afterwards was the result of the excesses of neo-liberalism that manifested itself after the collapse of checks and balances in the international system.

The current U.S. military and economic global hegemony is a mechanism that is used to deter, prevent or destroy any emerging regionalisms that threaten that hegemony. As a result, neo-liberalism has destabilized the international system and caused a number of conflicts and tensions of a military and economic nature. When the U.S. emerged from the Cold War as the sole superpower it was also a global informal empire. Historically the U.S. has used a combination of military and economic power in order to influence geopolitical regionalisms, such as the Marshall Plan in Western Europe after World War II as a means to gain influence and control, and at the same time to prevent Soviet influence and control.

A significant change took place in Brzezinski's thinking between 1997 and 2016, when he wrote Toward a Global Realignment, where he no longer boasts of the United States being an unchallenged global power. The challenges to U.S. power and influence came from China, Russia and a political reawakening in the Middle East and Muslim worlds (Brzezinski, 2017). The prediction that Russia, if it acts wisely, could become a leading country in Europe helps to explain a number of events and processes that have been happening from the early 2000s onwards. As such there has been a reaction to the seemingly "unstoppable" advance of global liberalism. "The emergence of these new forms of neo-liberal globalization and related forms of militarization pose some of the sharpest challenges for human security today" (Reifer, 2002). The waves of branded revolutions, in particular the Color Revolutions and the Arab Spring, can be seen in the light of Brzezinski's stated geostrategic goals within the framework of neoliberal expansionism. Thus far, the discussion has been based upon elite interactions within international politics and relations. However, modern technological developments have enabled geopolitics to be engaged at the popular level and not the sole preserve of the global elite.

This has led to the development of the concept and practice of popular geopolitics. The communication and representation of 
geopolitics in outlets of mass popular culture (movies, literature, music, social media, and mass media) have long shaped public opinion and perception of geopolitical conflict through offering an emotional and simplistic explanation and understanding of a projected reality (Sharp, 2000; Dittmer and Dodds, 2008; Dittmer and Gray, 2010; Downing, 2013). Popular geopolitics has had a focus on "tracing the ways in which popular media reinforce elite discourses" (Dittmer and Gray, 2010, p. 1665). One of the more recent outlets that enable a more equal playing field in popular geopolitics is found in the quality and quantity of communication in new media, including social media.

\section{NEW GEOPOLITICS IN NEW MEDIA}

There has been a marked shift in power and who possesses and wields it, from the traditional state-centred application of hard power to the virtual power of movements and individuals. For example, the Yellow Vests in France or massive corporations such as Google and Facebook. This has permanently changed the dynamics of global politics and power. Geopolitics in the age of new media has seen the transformation of the dynamics of geopolitics. Three significant shifts have been noted (Fraser, 2009): 1) states to individuals; 2) real world to virtual world mobilization and power; 3 ) from old media to new media. As such, it poses a significant challenge and risk to governments and states.

Social media has provided political actors with new capabilities and new opportunities. They can also be used as a means to tackle asymmetry in the hard power balance. Flint (2017, p. 97) observes that "the weapon of geopolitical representation in the battlefield of social media may favor the weak over the strong." Social media is like most other kinds of weapons insofar as its effectiveness or lack of it depends on the knowledge, ability and capability of the user. Significant differences exist in communication strategies executed that are based in traditional media (newspapers, TV, and radio) and those that are run in new media (Cunningham, 2010, p. 110). The failure to appreciate the differences and adapt can put a communicator at a significant disadvantage. The term 'Web 2.0 ' is a very specific one, which possibly dates back to as early as 2004 by some accounts and 


\section{Greg Simons}

occupies a segment of cyberspace. It is a highly interactive form of many to many communications. "The social web, often referred to as Web 2.0, is made up of a second generation set of software applications, enabling users to collaborate, work, and share online. It is characterized by popular web applications such as You Tube, Facebook, Twitter, Wikis, and myriad others" (Richter, 2012, p. 107).

As noted above, the communication in new media is a dialogic form, which is based upon a many-to-many message flow. Simultaneously the sending and receiving of information takes place. As such it offers a platform for social empowerment, a mechanism for organizing and mobilizing people for some form of change through activism. The Internet is well suited to transnational political activism through its "multiplicity and polycentrality; interactivity and crossborder participation" (Fenton, 2008, p. 233). The experience of the anti-globalization movements provides a case in point where the broad mix of ideological and international protestors, in spite of their lack of means and central authority, were able to leverage advantages over their more centralized and better equipped opponents through extensive use of new forms of communication (van Aelst and Walgrave, 2002, p. 486). Hart (2012, p. 212) noted that the proliferation of new information and communications technologies (ICTs) has created several effects: 1) new opportunities and capabilities for actors seeking to affect debates; 2) the power relationship between governments and citizens is altered allowing for easier and more rapid organization and mobilization of people for political purposes regardless of physical distance; and 3) created and reinforced new types of relationships in international relations between different stakeholders (citizens, corporations, governments, and so forth).

The events of the Arab Spring uprisings since 2011 demonstrated the use of digital means by Western governments to subvert foreign governments in an attempt to expand into the Middle East and North Africa region under the guise of exporting liberal values. There was an attempt to use the Arab Spring as a means of vindicating the universal appeal of Western liberal democracy via social and new media. However, there is also the rise of non-Western alliances and 
institutions (BRICS, for example) that challenge the Western-centric vision of the global order (Aouragh and Chakravartty, 2016). This has, in turn, created a context for a pushback by the current world order. This is seen in the increasingly hostile mainstream political and media narrative towards the projected hostile intentions of Russia, and increasingly China, with regard to the concept of Western liberal democracy.

Interesting enough, in spite of the overt use of fear to influence public opinion and behavior, it does not detract from the changes occurring in the public opinion of the world's most powerful countries. The World Report looks at the influence potential of a nation, including its political, economic, and military power. This was part of the media organization's annual "Best Countries" study that evaluated 80 countries based on responses from 21,000 people. In 2018, there was an obvious and significant shift from a Western-centric hierarchy, although the United States retained first place, with Russia and China holding second and third places, respectively, and there are a significant number of non-Western countries appearing (Baker, 2018). This large-scale public opinion survey hints at a significant shift in how the public view the evolution of the existing world order into a more multipolar and non-Western configuration.

\section{SHAPING PERCEPTION IN THE PHYSICAL DOMAIN}

Within the broader realm of information warfare (of which propaganda is part), there are three domains to be considered: the physical domain, the information domain, and the cognitive domain (Alberts et al, 2001, p. 10). In terms of the search for political and military influence, the domain that they seek to influence is the informational one in order to enable military operations and foreign policy in the physical domain. The general public's understanding of reality and "ground truth" can translate into increasing the possibility of combat or policy effectiveness and dominance. On the intangible side, information exists and is created in the information domain. It is shared and can be subjected to manipulation, which means that the information in it may not accurately reflect the ground truth. This domain concerns 


\section{Greg Simons}

the communication of information among and between the various vested actors. The information domain is subject to competition and interference from other actors present, which implies offensive and defensive dimensions to communication activities. The objective is to gain information superiority within the information domain over the adversary or over domestic voices opposed to the government's chosen policy position. The minds of the participants are found in the cognitive domain, which is "where perceptions, awareness, understanding, beliefs, and values reside, and where, as a result of sense making, decisions are made" (Alberts et al, 2001, p. 13). This is the domain in which physical battles are actually won or lost as it involves such crucial intangibles as leadership, morale, unit cohesion, level of training and experience, situational awareness, and public opinion. All content in this domain passes through the filtering process of human perception. Hence there is the importance and relevance of these three domains to the prosecution and operationalization of geopolitics in international relations.

The nature and character of the news content also create potential dilemmas or conflicts between expectations of mass media's idealized role as the fourth estate versus its active role in attempting to subjectively influence that debate and the resulting information. The more exact role of mainstream media is revealed, separating myth from reality, during highly political events that contain a certain element of risk for the political hegemony. Michael Goodwin, the chief political columnist for The New York Post reflected on journalistic standards in the 2016 U.S. presidential election. He reflected upon a time "not so long ago when journalists were trusted and admired. We were generally seen as trying to report the news in a fair and straightforward manner. Today all has changed" (Goodwin, 2017). Goodwin mentioned the content of mainstream media as being "distorted by intentional bias and hostility." The underlying reason he gave was that liberalism is deeply embedded in contemporary mainstream journalism. This situation creates the possibility of a conflict of interest arising in journalism if liberalism is challenged as there is a risk to "jump to its defence" that is against the notion of the fourth estate's role in favor 
of one where it can be in a subordinate role to the executive and/or legislative branches of government. The approach of selective outrage displayed by the media only has a façade of morality and is more akin to a fad, and is ultimately self-defeating (McCarthy, 2017).

When it comes to acts of war and aggression against non-liberal elements in global affairs, mainstream media follow uncritically the official narrative and agenda, promoting conflict through interpretive journalism, rather than assuming a "let the facts speak for themselves" approach. This is clearly seen in the events in Venezuela at the beginning of 2019 (McLeod, 2019). This is in line with the notion of information warfare and its functioning (Alberts, et. Al., 2001), where politically subjective representations of the physical domain are used in the information domain in order to shape and influence the cognitive domain. It is equally applicable in defensive operations where actors defends their intangible values, where moral panic can be used, in a relative context, to erode the opponent in favour of oneself (Simons and Sumskaya, 2018). Within the context of a new Cold War, the invocation of "foreign threats" is an example of the new geopolitics of fear. Pain (2010, p. 228) noted the manipulative use of fear within the Global War on Terrorism, where "government leaders have sought to reflect this fear, and instil it further, in speeches and election campaigns." The often cited projections of "Russian interference" or "meddling" is an example of defensive use of information warfare, where there are attempts to deflect and distract attention and focus from domestic sources of public discontent or self-inflicted weaknesses (economic crises and mass migration, for example) in a liberal democracy. Russia provides an example of the most useful and familiar Other to home audiences. It can also be applied in offensive operations, such as the current use and application for regime change in Syria and Venezuela, by attacking the intangible value of a target government.

Andrey Manoilo created categories for a series of different tools that can be employed against a geopolitical adversary. Firstly, the use of latent information management, which involves an opponent's internal, economic and cultural processes. The goal is to create an information environment that would influence decision-making 


\section{Greg Simons}

to the benefit of the manipulator. A second means is informationpsychological aggression based on economic, political and diplomatic pressure. For example, this could involve the use of some form of economic blockade in conjunction with an informational attack upon an opponent. A third variant is an information war based on economic blockade and threat of use of force (Maliukevicius, 2006, p. 131). These categorizations demonstrate the power of information and its use within the field of geopolitics.

In the current global context and evolving order, the category that makes the most sense for the challengers of the current order is the use of latent information management. Kofman $(2018$, p. 21) says Russia's competitive advantage over the United States is to be found in the domains of indirect warfare, especially political warfare and information operations. At the same time, it is understood that communications through mainstream media are not practical owing to their loyalty to the cause of global liberalism, and the fact that the public trust and therefore credibility of the message going through such a sender is less likely to be effective in persuading or influencing an audience.

\section{HEGEMONY AND THE EVOLVING INTERNATIONAL ORDER}

Buzan (2004, p. 45) observed that the concept of "polarity has been hugely influential in public debates about international relations." In the wake of the results of the end of the Cold War in 1991, and until approximately 2007, the United States attempted to expand its global influence by soft power means. An attempt was made through the policy that was based on the assumption of engaging with rivals through including them in international relations and commerce, which was intended to turn them into benign actors and trustworthy partners. However, this was found to be a false premise (National Security Strategy, 2017), in some cases the policies were of greater benefit to the rivals than the United States (such as "outsourcing" industrial production). This is increasingly obvious in the current global context of the debate on the challenge to the U.S. global hegemony and a possible transition from unipolarity to multipolarity. 
"The basis for hegemony is economic strength that translates into a dominant influence in global trade and finance. Maintenance of the capitalist world-economy in a form that benefits the hegemonic power requires, at times, military force" (Flint, 2017, p. 220).

Flint's understanding of hegemony is based mostly upon the notion of hard power, which is easier to measure, and tends to neglect the soft power effect that is also important. It is important as it enables opportunities to be accomplished on the basis of positive relationship dynamics and therefore the absence of sufficient means to coerce an actor. Hard power is more easily understood and seen owing to its tangible and rational form and presence, and soft power can be overlooked owing to its intangible and often more emotionally inclined form. The end of the Cold War and later the Global War on Terrorism have tended to reinforce U.S. attitudes and behaviors with regard to hegemony, where "the current unipolar international system has encouraged the United States to engage in policies designed to continue its pre-eminence and influence in global politics" (Krahmann, 2005, p. 542). However, this is based on hard power and the use of coercion. One of the points of erosion of U.S. hegemony is in the area of global green politics and declining soft power, where it is increasingly being seen as a new "rogue state," which has the effect of detracting from its perceived legitimacy and calls into question foreign policy actions (Falkner, 2005). This raises the question of managing the opposition to a hegemon.

One of the strategies used by political activism is to highlight the points of discontent in society and to articulate it in a value and/or norm-based form (in word and deed) that resonates emotionally in society as a means of challenging the existing hegemony and assisting mobilization (Maney, et., 2005). Challenges to the U.S. hegemony and the Western global liberal order are quite often dialectically opposed to reality within the context of political, social and economic justice (Carroll, 2007), but also to resistance to the global liberal projects of globalization and multiculturalism (Simons, 2015a). The perceived U.S. decline as a global hegemon has enabled other powers to begin to position themselves in competition and opposition. China and 


\section{Greg Simons}

Russia cooperate in presenting an opposition to this hegemony, where they rhetorically position themselves as offering a more equally based partnership of mutual interests as opposed to enforced adherence to dictated sets of "universal" norms and values in a dialectic opposition to the unpredictable and coercive behavior of the U.S. (Foot, 2006; Deyermond, 2009; Strange, 2011).

The above sections of this paper touched upon the concept of tangible (physical actions of an international actor) and intangible (relating to communication and representations of actors and events) elements and the kinds of influences and effects that result. However, it should be understood that these elements are not exclusive of each other in terms of their influence. Rather, the tangible and intangible elements influence the outcomes of each other. Western thinking tends to comprehend and understand the subordinate role of information as a means of supporting and legitimizing government policy and intent (intangible to support the tangible). Whereas, other actors (such as insurgent or terror groups) adhere to the role where tangible acts are subordinate to and support the intangible intent as a means of subverting the reputation of a more powerful adversary owing to the unequal ability in hard power projection.

A National Intelligence Council report (2012, p. iv) predicts that there will be a diffusion of power among countries and there will be a dramatic impact by 2030. "Asia will have surpassed North America and Europe combined in terms of global power, based upon GDP, population size, military spending and technological investment." A greater level of unpredictability and volatility has entered the international system, which remained stable in the Cold War period. A more forceful and risky path of confrontation by the rising nonWestern powers, such as China and Russia, creates a great deal of uncertainty and risk that was not attempted during the Cold War for these exact same reasons (Bordachev, 2018). The old system of international relations is gradually breaking down and evolving into something else. The forecasts go as far as to predict there will be no single hegemonic power, but rather power will shift to networks and coalitions in a multipolar world (Ibid, p. ii). Karaganov and Suslov 
argue that the Western decline in economic and military power has been going on for decades but has been particularly obvious in the last decade. "The main reason for the general confusion among Western elites and the tension in world politics and the international economy is the simultaneous decay of most global and regional international political and economic orders, by which we refer to systems of rules, norms and patterns of behavior accepted by a majority of actors at a particular time. This decay has been brewing for a long time but has only become visible in the last decade. Figuratively speaking, several tectonic plates on which the international order and its underlying concepts have stood have begun to move" (Karaganov and Suslov, 2018).

This shift has great implications for the state and functioning of the system of international relations, especially the current hierarchies of power and influence. Klieman (2015, p. 254) notes that "global politics are being transformed from decidedly hierarchical to less hierarchical, and when global power is shifting, making future international relations the work of many more hands." Flockhart (2016, pp. 25-26) states that there is a need to prepare the ground for the coming of a multi-order world. One of those suggested preparations was that there is an acceptance that liberal values are not universal. Another realization is that there is likely to be a "post-Western" system of global governance. This has implications for the current understanding and application of power and principle in international relations.

There are two themes that emerge, which are driving the transformation and have implications for the future course. These are, firstly, the rapid expansion of the current mid-level to great powers. And secondly, the situation poses a significant test for the current functioning of the international system (unipolar). This relates to whether or not the current hegemony is flexible and receptive enough to acknowledge this emerging constellation of power and influence voluntarily and incorporate them into the current structure (Klieman, 2015, pp. 254-255; Brooks and Wohlforth, 2016, pp. 60-63). In other words, will the U.S. attempt to preserve its status as a global unipolar hegemon, which is likely to require the use of force or will it yield 


\section{Greg Simons}

some power and influence in order to retain a say in the top tier of international actors? "Sorely challenged in the Arab Middle East and on other fronts from the Baltic to the Pacific, assailed and openly defied by Islamic militants, frustrated by insolvable global problems and confused by the complexities of foreign affairs while struggling to redefine its own role, nonetheless the United States will remain the force to be reckoned with" (Klieman, 2015, p. 257).

These multitudes of individual tensions and conflicts have been gradually sapping the strength of the U.S.-led global order, which has been largely self-inflicted actions of choice. There has been some very pointed critique aimed at the U.S. approach to the conflicts in Afghanistan, Iraq, and Syria by Anthony Cordesman. This criticism is centred on the fact that there have been three successive presidential administrations fighting wars that result in tactical victories, but without any clear strategy for ending any of the mentioned wars or bringing about stable peace. "It is dealing with major insurgencies or civil war as if they were limited terrorist movements. [...] It has no grand strategy and is fighting half a war (Cordesman, 2018)." Therefore, tactical and operational aspects of armed conflicts that the U.S. is currently entrenched in are harming its strategic interests and capacities. "Finally, the U.S. has adopted a new ideology of global polarization and division, presenting Russia and China in the most recent National Security Strategy and other influential documents as a kind of united authoritarian bloc of revisionist powers committed to undermining the existing international order and opposing the free world. This aims to unite allies and partners under U.S. leadership and win a global confrontation for the second time" (Karaganov and Suslov, 2018).

This is a policy and direction that carries various internal and external risks, and in general, it is undertaken from a position of weakness and not strength. Lukin (2016, p. 91) noted that the Soviet Union was the architect of its own demise, "the Soviet communist project had become uncompetitive, leading to its failure. Soviet ideology had cornered itself." As an illustrative lesson in the rise and fall of a great power, it is invaluable and should serve as a warning. 
One of the means of communication and interaction that is seen as holding potential to break this global impasse in the existing world order is the use of digital diplomacy. It is seen, simultaneously, as a means to defend and contest the existing world order by a wide range of state and non-state actors. Hence the latest frontline of the battle of global influence and persuasion is in social and new media.

As such, the Internet revolution has affected all aspects of human life, including international relations and the transformation of the concept and practice of foreign policy (Adesina, 2017). Social media hold the potential to foster dialogue and build relationships between governments and people. The dialogic communication is often limited to very specific issues, however, studies tend to demonstrate that foreign ministries fail to realize the full potential of digital diplomacy (choosing to focus a lot on bilateral/multilateral issues, economic news, current affairs, public relations, and e-government), using a monologic tone rather than fostering dialogue (Kampf et al, 2015). This means the communication logic supports a consumer and not prosumer approach, where the audience is treated as a passive receiver and not an active partner in co-production and collaboration.

The United States has had a long history of using new technology as a mechanism for engaging in public diplomacy. However, it has been relatively slow to make full use of Web 2.0 technologies; the inclination has been to push messages out, rather than to listen to feedback or international opinion from the outside world that may shape policies (Cull, 2013). This has implications in a world of intense global communication attention by diverse actors. "The worst error is to be irrelevant and the fastest route to irrelevance is for a public diplomacy actor to assume that its interests match those of the audience" (Cull, 2013, p. 136). There have been transformations in the approach to communicating by U.S. public diplomacy which is ultimately concerned with influence as being instrumental to consolidating or eroding power. "The locus of power appears more readily in recognizing the significance of networks of relations as tied to securing the strategic ends that ultimately warrant public diplomacy. Shaping the narrative is less important than the context of the message 


\section{Greg Simons}

being consumed" (Hayden, 2013, p. 212). The activity and intent of U.S. digital diplomacy is towards realizing foreign policy goals and the geopolitical imperatives that were named by Brzezinski (1997b), that is, maintaining its current status as a global hegemon, which is currently under pressure and threat. Other states challenge the U.S. position through their digital diplomacy efforts.

China and Russia have both developed the concept and practice of digital diplomacy quite rapidly, which is a means of public outreach to foreign publics in order to explain the official position on government policy and events that are unlikely to be carried in mainstream media (Simons, 2015b). On the one hand, there is an attempt to rationally justify and explain government policy and positions. But this is an exercise in public relations and not listening or building networks and coalitions. The apparent intent is to engage in negative publicity by pointing to the weaknesses in the liberal system and U.S. behavior on the international stage. This may possibly temporarily harness and mobilize public discontent, such as the loss of "traditional" values for conservatives or concern about the "aggressive" nature of U.S. foreign policy for the left. However, it does not build a network or a relationship.

In addition to the varying degrees of success, international activism (such as anti-Globalists, peace movements and environmentalists) demonstrates the power of communication in bringing people together for a common cause on a narrow spectrum of issues. But more needs to be offered in order to build and maintain a mutually beneficial relationship. Controversial as it is, the example of Islamic State's (IS) communications not only offered the negative and hateful communications in challenging the Western global order, they also included positive messages. These concerned projecting their utopian vision of society and offering the audience their "opportunity" to help build that vision and be part of an inclusive and meaningful project (Simons, 2018). The soft power of the IS message was to offer hope, meaning and to be part of a community when they lacked these aspects of higher meaning in their life, even if this was an illusion, it resonated to a segment of different publics. Although overly sensationalized, this 
demonstrates that some, often non-state actors, are much better placed to make more effective use of social media and new media than their state-based rivals. This may be influenced by the level of asymmetry faced, and therefore a necessity. But it does demonstrate the greater potential of social and new media in bringing about change.

\section{CONCLUSION}

Although the world order is transforming and evolving from a unipolar hegemony of the United States that props up liberal democracy, these changes were not initiated by digital factors. Rather the decay originated from the success and euphoria that came from the apparent "victory" in the Cold War, which in turn caused a number of strategic miscalculations concerning the strength and durability of their military power and the presumed universal sets of emotionally laden values and norms that replaced the concept interests. The values and norms are being imposed by force, based upon their assumed superiority, which has resulted in endless wars that have sapped the West's hard power, economic power, and soft power. The gradual transformation from a unipolar order to a more multipolar order seems to be well underway, and digital factors can be used to either slow or speed up the process.

Of course, social media and new media are playing a greater part in international relations and politics. They are being used as a means to defend the existing world order and as a means to undermine it. These new forms of media are potentially very potent instruments of influencing the course and discussions on the existing world order and its possible directions. They are able to unite diverse groups and individuals spread across the planet dedicated to specific issues. However, experience has shown that social media and new media are being used as a platform to communicate outwards, various official positions on different topics and not as a means for engaging in manyto-many dialogic communication that creates mutually reciprocal relationships. The audience needs to be a prosumer and not just a passive consumer based on a positive project of mutual benefit in order to better facilitate change. 


\section{Greg Simons}

There is a certain dilemma in including the public in global politics and relations, which has been until recently the sole preserve of the state and elite. In deciding whether there should be an acceptance of popular participation of the public in the events and processes of the global order, should it be on the basis of subject (active participant) or object (passive participant) as far as the state is concerned? Traditionally being passive objects of events, taking the path of a subject makes the outcome less certain in terms of the state being able to control the environment and secure its interests and objectives. But given the gradual evolution from a unipolar world order towards a multipolar one in a context of severe dysfunction in traditional diplomacy and governance, it makes sense as a means to try and break the current deadlock.

\section{References}

Adesina, O. S., 2017. Foreign policy in an era of digital diplomacy. Cogent Social Sciences, 3(1297175).

Van Aelst, P. and Walgrave, S., 2002. New media, new movements? The role of the Internet in shaping the 'anti-globalisation' movement. Information, Communication and Society, 5(4), pp. 465-493.

Alberts, D. S., Garstka, J. J., Hayes, R. E. and Signori, D. A., 2001. Understanding information age warfare. Washington DC: CCRP Publication Series.

Aouragh, M. and Chakravartty, P., 2016. Infrastructures of empire: towards a critical geopolitics of media and information studies. Media, Culture and Society, 38(4), pp. 559-575.

Baker, S., 2018. World's 25 most powerful countries from U.S. to Egypt. The Independent, 9 July [online]. Available at: <https://www.independent.co.uk/ news/world/world-most-powerful-countries-ranking-change-a8438711. html $>$ [Accessed 26 January 2019].

Bordachev, T. V., 2018. Revisionism of powers in the changing historical context: Why states change their foreign policy behaviour on the global stage. Russia in Global Affairs, 16(3), pp. 46-65. DOI: 10.31278/2618-9844-2018-16-3-46-65.

Brooks, S. G. and Wohlforth, W. C., 2016. America abroad: the United States' global role in the 21st century. New York: Oxford University Press. 
Browning, C. S., 2018. Geostrategies, geopolitics and ontological security in the eastern neighbourhood: the European Union and the 'New Cold War.' Political Geography, 62, pp. 106-115.

Brzezinski, Z., 1997a. A geostrategy for Eurasia. Commonwealth Institute, September/October [online]. Available at: <http://www.comw.org/pda/ fulltext/9709brzezinski.html> [Accessed 19 March 2018].

Brzezinski, Z., 1997b. The Grand chessboard: American primacy and its geostrategic imperatives. New York: Basic Books.

Brzezinski, Z., 2017. Toward a global realignment. American Interest, 17 April [online]. Available at: <https://www.the-american-interest.com/2016/04/17/ toward-a-global-realignment/> [Accessed 19 March 2018].

Buzan, B., 2004. The United States and the great powers: world politics in the 21st century. Cambridge: Polity.

Carroll, W. K., 2007. Hegemony and counter-hegemony in the global field. Studies in Social Justice, 1(1), pp. 36-66.

Ciuta, F. and Klinke, I., 2010. Lost in conceptualisation: reading the "New Cold War" with critical geopolitics. Political Geography, 29, pp. 323-332.

Cohen, S. B., 2003. Geopolitical realities and the United States foreign policy. Political Geography 22, pp. 1-33.

Cordesman, A. H., 2018. Losing by “winning”: America’s wars in Afghanistan, Iraq and Syria. CSIS, 13 August [online]. Available at: <https://www.csis. org/analysis/losing-winning-americas-wars-afghanistan-iraq-and-syria> [Accessed 23 August 2018].

Cull, N. J., 2013. The long road to public diplomacy 2.0: the Internet and U.S. public diplomacy. International Studies Review, 15, pp. 123-139.

Cunningham, T., 2010. Strategic communication in the new media sphere. JFQ Issue 59 4th Quarter, pp. 110-114.

Deyermond, R., 2009. Matrioshka hegemony? Multi-levelled hegemonic competition and security in post-Soviet Central Asia. Review of International Studies, 35, pp. 151-173.

Dittmer, J. and Gray, N., 2010. Popular geopolitics 2.0: new methodologies of the everyday. Geography Compass, 4(11), pp. 1664-1677.

Dittmer, J. and Dodds, K., 2008. Popular geopolitics past and future: fandom, identities and audiences. Geopolitics, 13(3), pp. 437-457.

Downing, J. D. H., 2013. "Geopolitics" and the "popular": an exploration. Popular Communication, 11(1), pp. 7-16. 


\section{Greg Simons}

Falkner, R., 2005. American hegemony and the global environment. International Studies Review, 7, pp. 585-599.

Fenton, N., 2008. Mediating hope: new media, politics and resistance. International Journal of Cultural Studies, 11(2), pp. 230-248.

Flint, C., 2017. Introduction to geopolitics. 3rd Edition. London: Routledge.

Flockhart, T., 2016. The coming multi-order world. Contemporary Security Policy, 37(1), pp. 3-30.

Foot, R., 2006. Chinese strategies in a U.S.-hegemonic global order: accommodating and hedging. International Affairs, 82(1), pp. 77-94.

Foster, J. B., January 2006. The new geopolitics of empire. Monthly Review, 57(8), pp. 1-18.

Fraser, M., 2009. Geopolitics 2.0. ARI, 144.

Goodwin, M., 2017. The 2016 election and the demise of journalistic standards. Imprimis, May/June, 5/6(46), 16 June [online]. Available at: $<$ https://imprimis. hillsdale.edu/2016-election-demise-journalistic-standards/> [Accessed 26 June 2017].

Hart, J. A., 2012. Information and communications technologies and power. In: S. S. Costigan and J. Perry (eds.). Cyberspace and global affairs. Farnham: Ashgate, pp. 203-214.

Hayden, C., 2013. Logics of narrative and networks in U.S. public diplomacy: communication power and U.S. strategic engagement. Journal of International Communication, 19(2), pp. 196-218.

Jay, P., 1979. Regionalism as geopolitics. Foreign Affairs 58(3), America and the World, pp. 485-514.

Kampf, R., Manor, I. and Segev, E., 2015. Digital diplomacy 2.0? A crossnational comparison of public engagement in Facebook and Twitter. The Hague Journal of Diplomacy, 10, pp. 331-362.

Karaganov, S. and Suslov, D., 2018. A new world order: a view from Russia. Russia in Global Affairs, 4 October [online]. Available at: <https://eng. globalaffairs.ru/pubcol/A-new-world-order-A-view-from-Russia--19782> [Accessed 20 October 2018].

Klieman, A., 2015. In conclusion: towards a new equilibrium. In: Klieman, A. (ed.). Great powers and geopolitics: international affairs in a rebalancing world. Cham: Springer, pp. 253-263.

Kofman, M., 2018. Great power competition in the 21st century. Valdai Papers, $\# 84$. 
Krahmann, E., 2005. American hegemony or global governance? Competing visons of international security. International Studies Review, 7, pp. 531-545.

Lukin, A., 2016. Russia in a post-bipolar world. Survival, 58(1), pp. 91-112.

McCarthy, D., 2017. The media's self-defeating outrage over Trump and Russia. The National Interest, 8 February [online]. Available at: $<$ https://nationalinterest. org/feature/the-medias-self-defeating-outrage-over-trump-russia-19374> [Accessed 10 February 2017].

McLeod, A., 2019. 'Resistance' media side with Trump to promote coup in Venezuela. Fairness and Accuracy in Reporting, 25 January [online]. Available at: $\quad<$ https://fair.org/home/resistance-media-side-with-trump-to-promotecoup-in-venezuela/?awt_l=LHpqG\&awt_m=iAoY9fmr42R._TQ $>$ [Accessed 26 January 2019].

Maliukevicius, N., 2006. Geopolitics and information warfare: Russia’s approach. Lithuanian Strategic Annual Review, pp. 121-146.

Maney, G. M., Woehrle, L. M. and Coy, P. G., 2005. Harnessing and challenging hegemony: the U.S. peace movement after 9/11. Sociological Perspectives, 48(3), pp. 357-381.

National Intelligence Council, 2012. Global trends 2030: alternative worlds. A Publication of the National Intelligence Council, NIC 2012-001.

National Security Strategy of the United States of America, 2017. Washington DC: White House. Available at: <https://www.whitehouse.gov/wp-content/ uploads/2017/12/NSS-Final-12-18-2017-0905.pdf>.

Pain, R., 2010. The new geopolitics of fear. Geography Compass, 4(3), pp. 226-240.

Reifer, T. E., 2002. Geopolitics, globalisation and alternative regionalisms. Transnational Institute, 1 September [online]. Available at: $<$ https://www.tni. org/es/node/11420> [Accessed 14 June 2017].

Richter, H. R., 2012. Web 2.0 and public diplomacy. In: Costigan, S. S. and Perry, J. (eds.). Cyberspace and global affairs. Farnham: Ashgate, pp. 105-118.

Rumley, D., 2005. The geopolitics of Asia-Pacific regionalism in the 21st century. The Otemon Journal of Australian Studies, 31, pp. 5-27.

Sharp, J., 2000. Condensing the Cold War: Reader's Digest and American identity. Minneapolis (MN): University of Minnesota Press.

Simons, G., 2015a. Aspects of Putin's appeal to international publics. Global Affairs, 1(2), pp. 205-208. 


\section{Greg Simons}

Simons, G., 2015b. Taking new public diplomacy online: China and Russia. Journal of Place Branding and Public Diplomacy, 11, pp. 111-124.

Simons, G., 2018. Brand ISIS: interactions of the tangible and intangible environments. Journal of Political Marketing.

Simons, G. and Sumskaya, A., 2018. Kontseptsiya "moral'noī paniki" v sovremennoī mediareal'nosti Rossii i Zapada: opyt vospriyatiya s pozitsii kommunikativno-kul'turnoī pamyati [Concept of "moral panic" in the present media reality of Russia and the West: experience of perception from the position of communicative culture memory]. Znak, 3(29), pp. 184-196.

Starr, H. and Siverson, R. M., 1990. Alliances and geopolitics. Political Geography Quarterly, Vol. 9(3), pp. 232-248.

Strange, G., 2011. China's post-Listian rise: beyond radical globalisation theory and the political economy of neoliberal hegemony. New Political Economy, 16(5), pp. 539-559.

Tsantoulis, Y., 2009. Geopolitics, (sub)regionalism, discourse and a troubled 'power triangle' in the Black Sea. Southeast European and Black Sea Studies, 9(3), pp. 243-258.

Tuathail, G. Ó and Agnew, J., 1992. Geopolitics and discourse: practical geopolitical reasoning in American foreign policy. Political Geography 11(2), pp. 190-204.

Vilanova, P., 2013. The fragmentation of political science and "methodological pluralism": regionalism and geopolitics. Geopolitica(s) 4(1), pp. 11-33. 